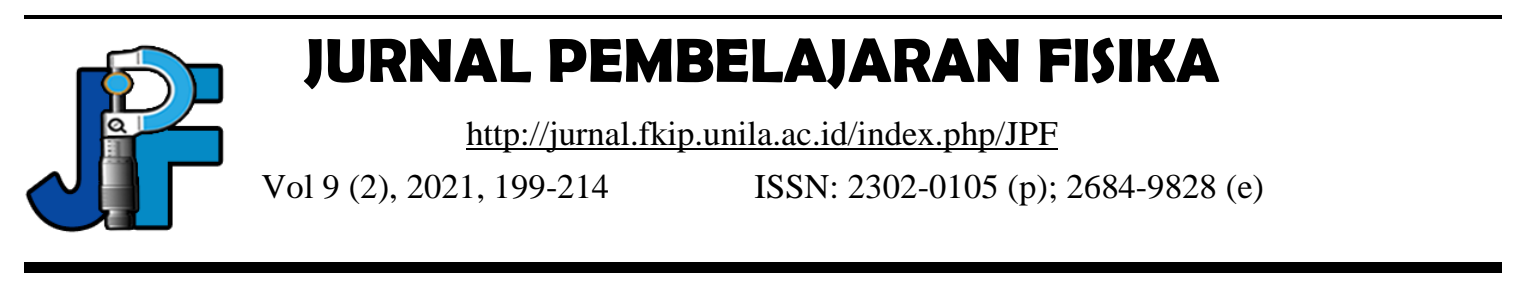

\title{
Development of Mechatronics Trainers as Practical Learning Media for Electrical Engineering Vocational Education Students
}

\author{
Irwanto Irwanto*, Ratna Ekawati \\ Sultan Ageng Tirtayasa University, Serang City-Banten, Indonesia \\ *e-mail: irwanto.ir@untirta.ac.id
}

Received: September 5, 2021

Accepted: December 30, 2021

Published: December 31, 2021

\begin{abstract}
This study aims to produce a mechatronics trainer and jobsheet product as a practical learning medium in mechatronics courses, as well as to determine the feasibility level of mechatronics trainer and jobsheet products. The research method used is development research. The development used adopts the ADDIE model which consists of five stages, namely analyze, design, development, implementation, and evaluation. Data collection techniques used include interviews, observations, and questionnaires. Testing the feasibility level of the mechatronics trainer involving four media experts and four material experts, as well as users was carried out by students of the sixth semester of 2018 electrical engineering vocational education study program. The data analysis technique used is descriptive qualitative and quantitative analysis. The results obtained for the media expert feasibility test score of 93.63 with a very decent category, for the material expert score obtained 90.76 including the very feasible category, and the results obtained from users with a score of 88.76 so it can be stated that mechatronics trainers and jobsheets can be used as media mechatronic practice learning in the electrical engineering vocational education study program
\end{abstract}

Keywords: development, mechatronics, practice, media, learning

DOI: http://dx.doi.org/10.23960/jpf.v9.n2.202107 


\section{INTRODUCTION}

The era of rapid technological and educational change, and adapting and responding to changes that require new knowledge, skills, and dispositions (Wahyudi, Hendra Jaya, Edy Sabara, 2020). One of them occurs in most industrial factories that choose to reduce human resources, namely the number of employees and replace them with machine power. This is due to the effectiveness and efficiency of time and the amount of production of goods which is certainly increasing. The era of the industrial revolution generation 4.0 which is marked by increased connectivity, interaction and development of digital systems, artificial intelligence, and virtual. With the increasingly convergent boundaries between humans, machines and other resources, information and communication technology certainly has an impact on various sectors of life. One of them is having an impact on the education system in Indonesia (Lase, 2019).

In Law (UU) Number 20 of 2003 concerning education, it is stated that education is a conscious and planned effort to create a learning atmosphere and learning process so that students actively develop their potential to have religious spiritual strength, self-control, personality, intelligence, morals. noble character, as well as the skills needed by himself, society, nation and state. This education is organized by empowering all components of society through participation in the implementation and control of the quality of education services. Education is a process that occurs in every human being. Naturally, humans grow and develop from in the womb until death, undergoing a process step by step.

Likewise, the occurrence of this universe was created by God through a levelby-level process, so that education plays a very important role in shaping the good or bad of the human person according to normative standards. Realizing this, the government is very serious about fixing the education system, because with a good education system, it is hoped that the next generation of quality will emerge and be able to adapt to live in society, nation and state. Learning as a process is a system that involves various parts including educators, students, teaching materials, students, learning resources, learning media, and methods. The success of learning is very much determined if the learning can grow and develop the potentials of students, so that students can benefit directly in their personal development. These components include objectives, teachers, students, methods, media (facilities and infrastructure), as well as evaluation and all components are interrelated so that it is easy to achieve the goals to be achieved. A generation that is responsive and ready to face the challenges of its era, without being uprooted from its nation's cultural roots (Tohir, 2020).

Vocational education is basically education to develop or drive economic activity, because vocational education is designed to meet the needs of the labor market and it is clear that this will make a positive contribution to the world of productive work that produces goods and commodities that have economic value, then collectively productive labor. which are able to produce goods of accumulative value will move the wheels of the economy and this will affect national economic growth. Vocational Education or Vocational Education (VE) is education for the world of work (Education for Vocation or Education for Occupations). Vocational Education is education to develop a person's work spirit so that he has the capacity or capability to be assigned or given orders to do certain jobs or positions (Sudira, 2016). 
Learning materials in learning are one of the components that must exist, because learning materials are several components that must be studied, observed, studied and made materials that will be mastered by students and at the same time can provide instructions for studying them. Engineering Science is a field of science that studies the implementation of new technologies in engineering sectors such as manufacturing, maintenance and management. The Electrical Engineering Vocational Education study program at Sultan Ageng Tirtayasa University produces quality Vocational High School teachers, both in terms of affective, cognitive and psychomotor abilities (John Aldi Prapaskah, 2020).

From the statement above, facilities and infrastructure are needed to support learning in strengthening skill competencies in students. One of the challenges faced by the Electrical Engineering Vocational Education Study Program is how to provide learning media that can support the student learning process, especially in mechatronics practice activities. In practical activities, the use of learning media has a significant influence on students in understanding the material being taught (Rizki Bayu Cahyadi, 2014). Learning media is anything that can be used to channel messages from sender to receiver, so that it can stimulate students' thoughts, feelings, concerns and interests for the learning process to occur (Sadiman, 2011). One of the teaching materials that can help students understand the material presented is modules and textbooks (Daryanto, 2013) (Ogata \& Katsuhiko, 2002). Modules and textbooks are considered necessary to be developed so that students can understand the material in accordance with the RPS (Semester Lecture Design).

The development of trainers and jobsheets is expected to meet the needs of students in reviewing material from the Mechatronics Practice Course. The development of learning media is expected to overcome these problems. In order to overcome the lack of time in the learning process, ease of use, and to increase understanding of the material and student motivation in learning in the classroom, the trainer learning media was chosen. Trainers can be used easily by lecturers and students can be active in the learning process, therefore the development of this learning media uses a mechatronic trainer (Benny A. Prasetyo, et al, 2017). The limitations of learning media make it difficult for students to understand the teaching material. Lack of understanding in theory also has an impact on practical ability because students still do not understand the theory, so this learning media is very much needed by lecturers and students. Learning is a process of student interaction with lecturers and learning resources in a learning environment. There are several components that must be met in the learning process. One of these components is learning media. Media is any tool that can be used as a channel for messages to achieve teaching goals (Djamarah \& Zain, 2006). Learning media functions as teaching aids that affect the learning environment that is organized and created by the lecturer.

Direct learning is one of the teaching approaches that can help students learn basic skills and obtain information that can be taught step by step (Nur, 2005). The direct learning model is based on the principles of behavioral psychology and social learning theory. This learning model is specifically designed to support student learning processes related to well-structured procedural and declarative knowledge, which can be taught with a gradual activity pattern (Nur, 2005). Direct learning is a lecturer-centered learning model that is presented in five stages, namely: (1) Delivery of objectives; (2) 
Demonstrating knowledge or skills; (3) Provide guided practice or training; (4) Check students' understanding and provide feedback; (5) Expanded practice and transfer. In the teaching and learning process, direct learning models can be in the form of lectures, demonstrations, training or practice and group work. A lecturer can also relate to class discussions and cooperative learning strategies.

This section provides Undergraduate, Postgraduate and Internship Programs. One of them is Vocational Education in Electrical Engineering, Faculty of Teacher Training and Education, Sultan Ageng Tirtayasa University, in the field of Vocational Electrical Engineering 2 branches of science, namely Industrial Automation Systems, and Power Systems. There are various courses offered by the study program, one of which is the practical mechatronics course which learns about how to work, implementation, infrastructure, engineering and others. Mechatronics is a skill that combines abilities in the fields of mechanics, electronics and computers. The basic skills that must be possessed in studying Mechatronics are the ability in the fields of mathematics, physics, mechanics, electronics and computer programming with highlevel languages. While the skills that must be possessed to study advanced Mechatronics are (Anonymous, 2002): (1) Mathematics includes numerical methods, transformations, and simulation methods. (2) Advanced computer programming, including object-oriented programming and software engineering. (3) Setting technique includes Laplace transform, digital arrangement and system analysis. (4) Computer science includes microcomputer systems, microprocessors, PLCs and so on. (5) The mechatronic system includes sensors, processes, actuators, and actuators. (6) Mechanics include vibration, deformation, kinematic and kinetic. (7) Manufacturing, including production technology and management. Thus Mechatronics is a truly complex skill. Mechatronics is a compulsory subject that must be taken by undergraduate students of the Electrical Engineering Vocational Education study program. This course has a weight that varies in each university between 2-3 credits, so the time to study this course is really limited (Aris Zainul Muttaqin, 2007).

The background of the problems that have been stated above, the development of learning media for mechatronics practical courses is considered important, because the related problems that can be identified are: (1) An urgent need for lecturers and students for learning media for mechatronics practical courses for students of the Vocational Education Study Program Electrical Engineering in order to meet the demands of learning in the Electrical Engineering Vocational Education Study Program; (2) Limited mechatronics practice media in the Electrical Engineering Vocational Education Study Program that is relevant/in accordance with industry needs; (3) Mechatronics Practice Learning requires learning media that are in accordance with the characteristics of students of the Electrical Engineering Vocational Education Study Program; (4) Charles Prosser's theory which says that learning will be effective if it is carried out specifically and directly on the problem by following the existing reflections in the industry.

The research objectives are: (1) To develop a mechatronic trainer as a practical learning medium for Mechatronics courses in the Electrical Engineering Vocational Education study program, Faculty of Teacher Training and Education, Sultan Ageng Tirtayasa University; (2) Knowing the level of feasibility of the mechatronics trainer as a learning medium for mechatronics practice in the Electrical Engineering Vocational 
Education study program, Faculty of Teacher Training and Education, Sultan Ageng Tirtayasa University.

\section{METHOD}

The type of research used is Research and Development (R\&D). Research and Development method or also called research and development is a research method used to produce products and test the validity, practicality, and effectiveness of products. This development research using 4D theory or model is carried out in 4 stages, namely (1) Definition, (2) Design, (3) Development, (4) Dissemination.

\section{Research Design \& Procedures}

The following is the research flow used which has been additionally modified, which can be seen in Figure 1 below.

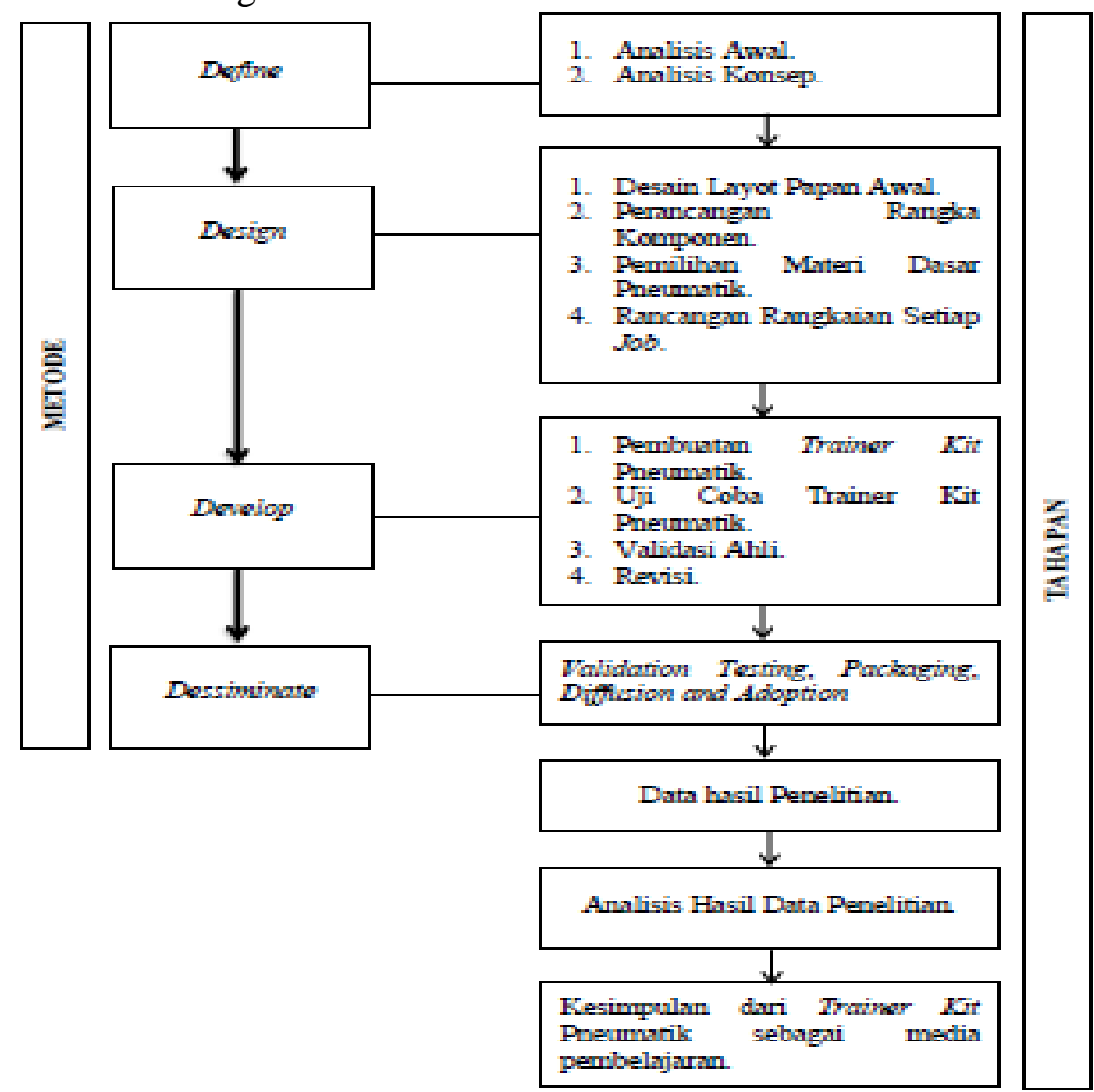

Figure 1. Research procedures on the 4D model

\section{Population and Sample}

The trial subjects or respondents in this study were addressed to students of the Electrical Engineering Vocational Education study program, FKIP Sultan Ageng 
Tirtayasa University batch 2018 semester 6. The number of samples of students from the 2018 Electrical Engineering Vocational Education study program was 32 students.

Product testing is carried out in four steps, namely testing product functionality, testing material experts, testing media experts, and testing users. The object of this research is a pneumatic mechatronics trainer equipped with a learning module. The research was carried out from April to May 2021 in the laboratory of the Electrical Engineering Vocational Education study program, Sultan Ageng Tirtayasa University. The research method used is Research and Development (R\&D) research. According to Sugiyono (2018), the research and development method or in English Research and Development $(\mathrm{R} \& \mathrm{D})$ is a research method used to produce certain products and test the feasibility of the products that have been made.

\section{Data Collection and Instrument}

Data collection techniques and instruments are intended to obtain the data needed in the implementation of research which is then analyzed. The techniques used in data collection in this study are by:

\section{Observation}

Data retrieval is carried out using tables that have been previously created directly in the laboratory of the Electrical Engineering Vocational Education study program.

\section{Interview}

This data retrieval, obtained by interviewing resource persons from the head of the laboratory and laboratory assistants in the Electrical Engineering Vocational Education study program directly.

\section{Library Studies}

\section{Questionnaire}

Questionnaire is a list of statements given to other people who are willing to respond (respondents) according to the researcher's request. The purpose of distributing the questionnaire is to find complete information about a problem from the respondent without feeling worried if the respondent gives answers that are not in accordance with reality in filling out the list of questions. In this study, the purpose of this study was to assess the suitability of the trainer developed with the stated objectives and to determine the feasibility of the Pneumatic learning worksheet. The questionnaire in this study was addressed to media experts and material experts. For students is a feasibility test questionnaire.

According to Sugiyono (2018), in principle, research instruments are tools that can be used in measuring the observed social and natural phenomena. The research instruments used in this study were observation sheets, interview question sheets and standardized questionnaire sheets. The following are the instruments used in the research: 
The Observation Instrument aims to determine whether the product made already exists or not and also as a basic reference for the research. The observation instrument used is unstructured observation, where researchers do not know what variables to observe.

The interview question instrument aims to find out directly the opinions of the sources whose data is taken. This instrument is usually used as reinforcement on the background of the problem. The interviews conducted were unstructured interviews, where the researchers did not use interview guidelines that had been arranged systematically.

The instrument of feasibility test by media experts aims to assess the quality of research products which contain points about aspects of learning media including aspects of technical quality and instructional quality.

The instrument of feasibility test by material experts is used to assess learning materials from the aspect of learning design including aspects of the quality of content and objectives, as well as instructional quality. The content of the instrument for learning material experts covers aspects of the quality of the content and objectives as well as the quality of instruction (instructions/steps).

The feasibility test instrument aims to determine whether or not a product is feasible or not. The feasibility test instrument sheet consists of a product feasibility sheet only which is compiled using a Likert scale. The making of this instrument refers to the research instruments that have been done previously, or it can be said that the instruments are already standardized. In preparing this validity sheet, it was tested on students of the Electrical Engineering Vocational Education study program, especially for the sixth semester or 2018 class students.

\section{Data Analysis}

Data analysis in this study was carried out after data from material experts and media experts were collected. Data analysis activities include grouping data based on variables and types of respondents, tabulating data based on variables and types of respondents, presenting data for each variable studied, and performing calculations to answer the problem formulation. The data analysis technique in this research is descriptive statistics. According to Sugiyono (2018), analyzing data by describing or describing the data as they are without making conclusions that apply to the public. The analysis in this study intends to show the results of the study, namely the feasibility level of the pneumatic trainer kit media.

The data obtained from respondents through this research instrument is in the form of qualitative data which is then quantified. To analyze it, the following steps were carried out.

\section{a. Calculating Score}

The scale used in the instrument is a four Likert scale, so this initial step is to calculate the score on each instrument item given to the respondent. The provisions for calculating the score can be seen in Table 1 below. 
Table 1. Score conversion

\begin{tabular}{ccc}
\hline Evaluation & Description & Score \\
\hline ST & Strongly Agree & 4 \\
\hline S & Agree & 3 \\
\hline T & Do Not Agree & 2 \\
\hline STS & Strongly Disagree & 1 \\
\hline \multicolumn{3}{c}{ (Source: Djemari Mardapi, 2008) }
\end{tabular}

\section{b. Calculating Average Score}

After tabulating all the data and calculating the score on each instrument item, the average score was calculated. The average score calculation uses the following formula:

$$
\bar{x}=\frac{\sum X}{n}
$$

Information:

$\bar{X}=$ average score

$\Sigma=$ total score of respondents

$\mathrm{n}=$ number of instrument items

\section{c. Converting Average Score to Score with Criteria}

To determine the feasibility of a pneumatic trainer kit, the data that was initially scored will be converted into interval data with four scales. According to Djemari Mardapi (2008), the reference in scoring into a scale of four can be seen in Table 2 below:

Table 2. Reference to change the score to a scale of four.

\begin{tabular}{cccl}
\hline No & Score Range & Score & Category \\
\hline $\mathbf{1}$ & $\mathrm{X} \geq \mathrm{X}+1 . \mathrm{SBx}$ & $\mathrm{A}$ & So Worth it \\
\hline $\mathbf{2}$ & $\mathrm{X}+1 . \mathrm{SBx}>\mathrm{X} \geq \mathrm{X}$ & $\mathrm{B}$ & Worthy \\
\hline $\mathbf{3}$ & $\mathrm{X}>\mathrm{X} \geq \mathrm{X}-1 . \mathrm{SBx}$ & $\mathrm{C}$ & Quite Decent \\
\hline $\mathbf{4}$ & $\mathrm{X}<\mathrm{X}-1 . \mathrm{SBx}$ & $\mathrm{D}$ & Very Unworthy
\end{tabular}

Information:

$$
\begin{aligned}
\overline{\boldsymbol{x}} & =\text { Average overall score } \\
& \left.=\frac{1}{2} \text { (maximum score }+ \text { minimum score }\right) \\
\mathrm{SBx} & =\text { Standard deviation of overall score } \\
& \left.=\frac{1}{2} \text { (maximum score }- \text { minimum score }\right) \\
\mathrm{X} & =\text { Score obtained }
\end{aligned}
$$




\section{RESULT AND DISCUSSION}

The development of the mechatronics trainer as a practical learning medium uses development research with a 4D model which has 4 stages of development, namely (1) Definition, (2) Design, (3) Development, (4) Dissemination, the explanation is as follows:

\section{Definition}

In the initial analysis stage, it is very necessary to develop learning media and feasibility studies as well as the requirements for developing mechatronics trainer learning media as a practical medium in the Electrical Engineering Vocational Education study program, Faculty of Teacher Training and Education, Sultan Ageng Tirtayasa University. Changing times such as industry 4.0 brought a big change in the use of learning technology, especially in vocational education. The trainer learning media as a practice medium is the basis of the mechatronics trainer media which was developed to fulfill learning achievements that are in accordance with the replicas that exist in the industrial world.

This research requires a proportional time, because it can be said that to produce a good and correct hardware, an appropriate procedure is needed. In making a mechatronic Trianer as a practical learning medium, it is an answer to an idea that arises as a practical learning need, especially in mechatronics courses after conducting interviews and field observations in the electrical engineering vocational laboratory in the Electrical Engineering Vocational Education study program, Faculty of Teacher Training and Education, Sultan Ageng Tirtayasa University.

The Indonesian National Work Competency Standard (SKKNI) in the Industrial Automation Sector in mapping competency standards has the main goal of increasing the efficiency and productivity of the production system (Wahyudi, Hendra Jaya, Edy Sabara, 2020). In line with the industrial revolution 4.0 in the process of improving the automation function, this mechatronics trainer media was developed with an Internet-based automation function with material based on learning outcomes at universities. The material taken to be a source of media creation is material that is in accordance with the needs which is summarized from the competence of technical expertise in Electrical Engineering Vocational Education. The material covered is material in the practical mechatronics course.

\section{Design}

From the description of the discussion at the needs analysis stage, the next stage is to design a trainer as a practical learning medium. In this study, there were 2 output products developed, namely media trainers and practical worksheets. Learning Media is made based on learning achievement. The material covered is material in the practical mechatronics course.

Defining is a stage in determining a problem which is examined in the observation step to determine the conditions in the Electrical Engineering Vocational Education laboratory, Faculty of Teacher Training and Education, Sultan Ageng Tirtayasa University. The design section is an activity stage in the initial design in making the mechatronics trainer media and the mechatronics trainer josbheet contained in the initial layout making step to determine the placement of each component, making cover designs on the pneumatic trainer jobsheet, searching for material on josbheet and designing the framework to place the trainer board. 


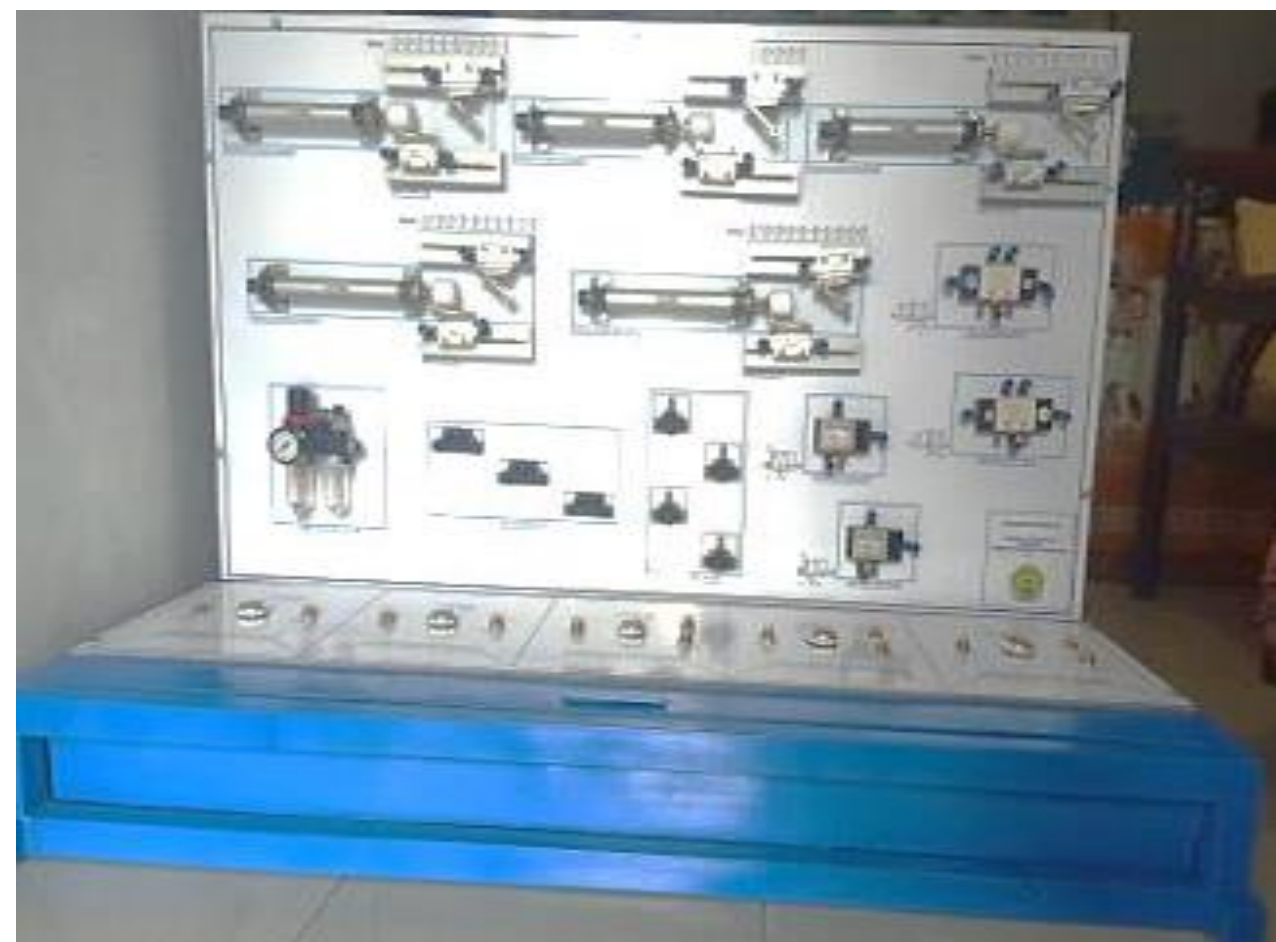

Figure 2. Mechatronics trainer media

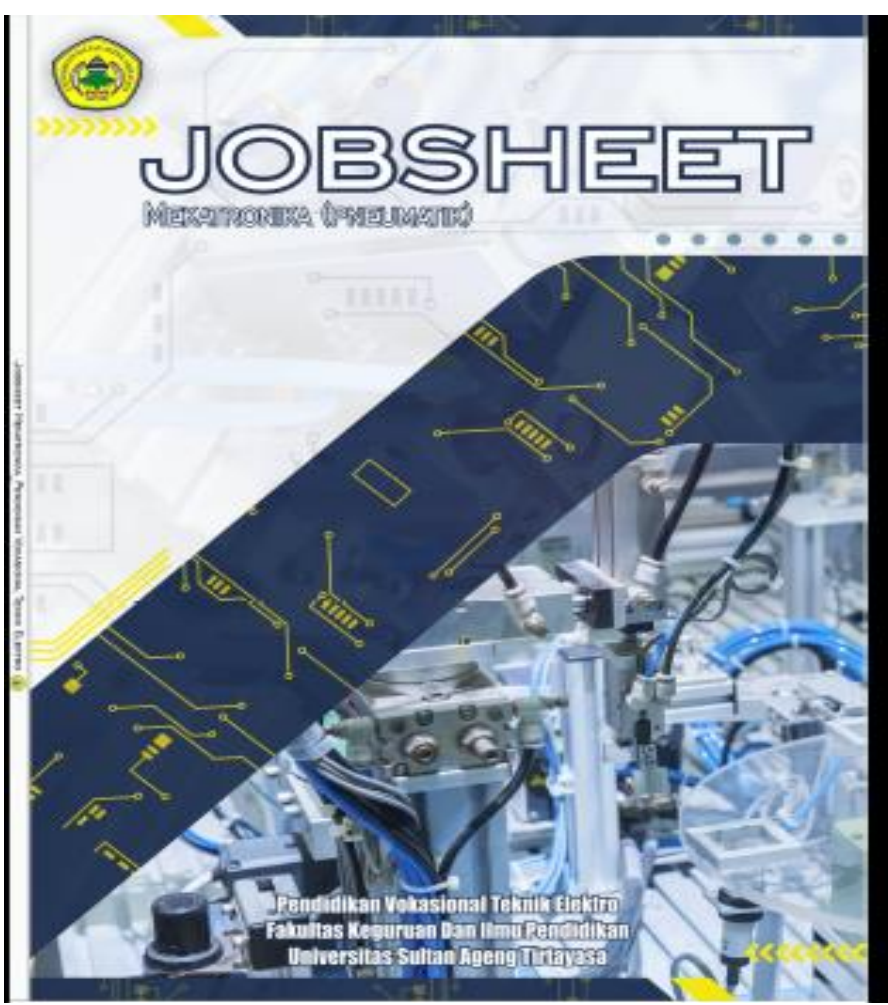

Figure 3. Mechatronics trainer jobsheet 


\section{Development}

Based on the media that has been designed by researchers at the design stage, the next stage is to carry out the development stage by looking at the responses of validators or experts from the designs that have been made, namely the feasibility of the media and the feasibility of the material and the feasibility of users for sixth semester students. From Figure $2 \&$ Figure 3 are the results of making mechatronics trainer learning media and mechatronics trainer josbheet which have passed the revision stage 1 time, then the mechatronics trainer and jobsheet trainer were tested for feasibility by media experts and material experts. after getting the results of the feasibility test, then knowing the user responses of the sixth semester of 2018 class of Electrical Engineering Vocational Education study program, Faculty of Teacher Training and Education, University of Sultan Ageng Tirtayasa.

The mechatronics trainer media feasibility test was carried out at the stage of making mechatronics trainer learning media. The mechatronics trainer feasibility test was carried out by three media experts from lecturers, teachers and industry using media feasibility test instruments, following can be seen the results of the media expert feasibility test in Table 3 which is presented with the scores of the feasibility test results by media experts in each aspect.

Table 3. The results of the media expert feasibility test

\begin{tabular}{|c|c|c|c|c|c|}
\hline \multirow[t]{2}{*}{ No } & \multirow[t]{2}{*}{ Respondent } & \multicolumn{2}{|c|}{ Criteria Aspect } & \multirow{2}{*}{$\begin{array}{l}\text { Total } \\
\text { Score }\end{array}$} & \multirow[t]{2}{*}{ Category } \\
\hline & & $\begin{array}{c}\text { Technical } \\
\text { Quality }\end{array}$ & $\begin{array}{c}\text { Instructional } \\
\text { Quality }\end{array}$ & & \\
\hline 1 & Lecturer & 45 & 45 & 90 & \\
\hline 2 & Teacher & 46 & 46 & 92 & very good \\
\hline \multirow[t]{2}{*}{3} & Industry & 42 & 45 & 87 & \\
\hline & & age Score & & 89.6 & \\
\hline
\end{tabular}




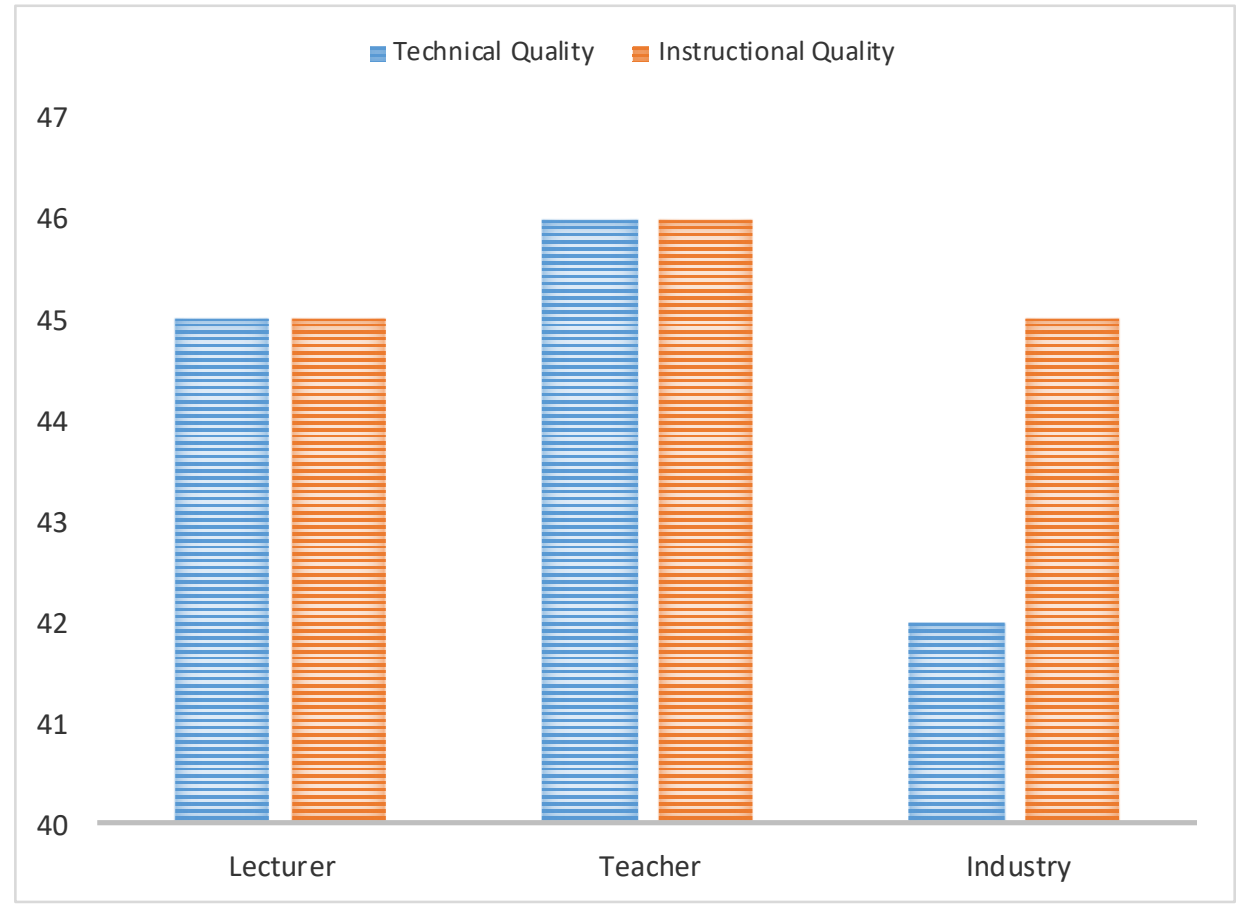

Figure 4. Media expert scores

Thus the total score obtained with the average score is 89.6 which states that it is in the interval X 89.6 so that the mechatronics trainer product is categorized as very suitable to be used as a learning media for mechatronics practice. The results of the media validation show that the criteria are very feasible for the application and device aspects and the display is based on quantitative data from the validator's questionnaire and is supported by general comments and suggestions. The conclusion of the media validation results stated that the media was feasible for field trials.

Table 4. The results of the material expert's feasibility test

\begin{tabular}{llllll}
\hline No & Respondent & \multicolumn{2}{c}{ Criteria Aspect } & $\begin{array}{c}\text { Total } \\
\text { Score }\end{array}$ & Category \\
\cline { 2 - 5 } & & $\begin{array}{c}\text { Quality } \\
\text { of } \\
\text { Content } \\
\text { and } \\
\text { Purpose }\end{array}$ & $\begin{array}{c}\text { Instructional } \\
\text { Quality }\end{array}$ & & \\
& & & & \\
\hline 1 & Lecturer & 41 & 41 & 82 & \multirow{2}{*}{ Very Good } \\
\hline 2 & Teacher & 42 & 43 & 85 & \\
\hline 3 & Industry & 43 & 45 & 88 & \\
\hline & & Average Score & $\mathbf{8 5}$ & \\
\hline
\end{tabular}




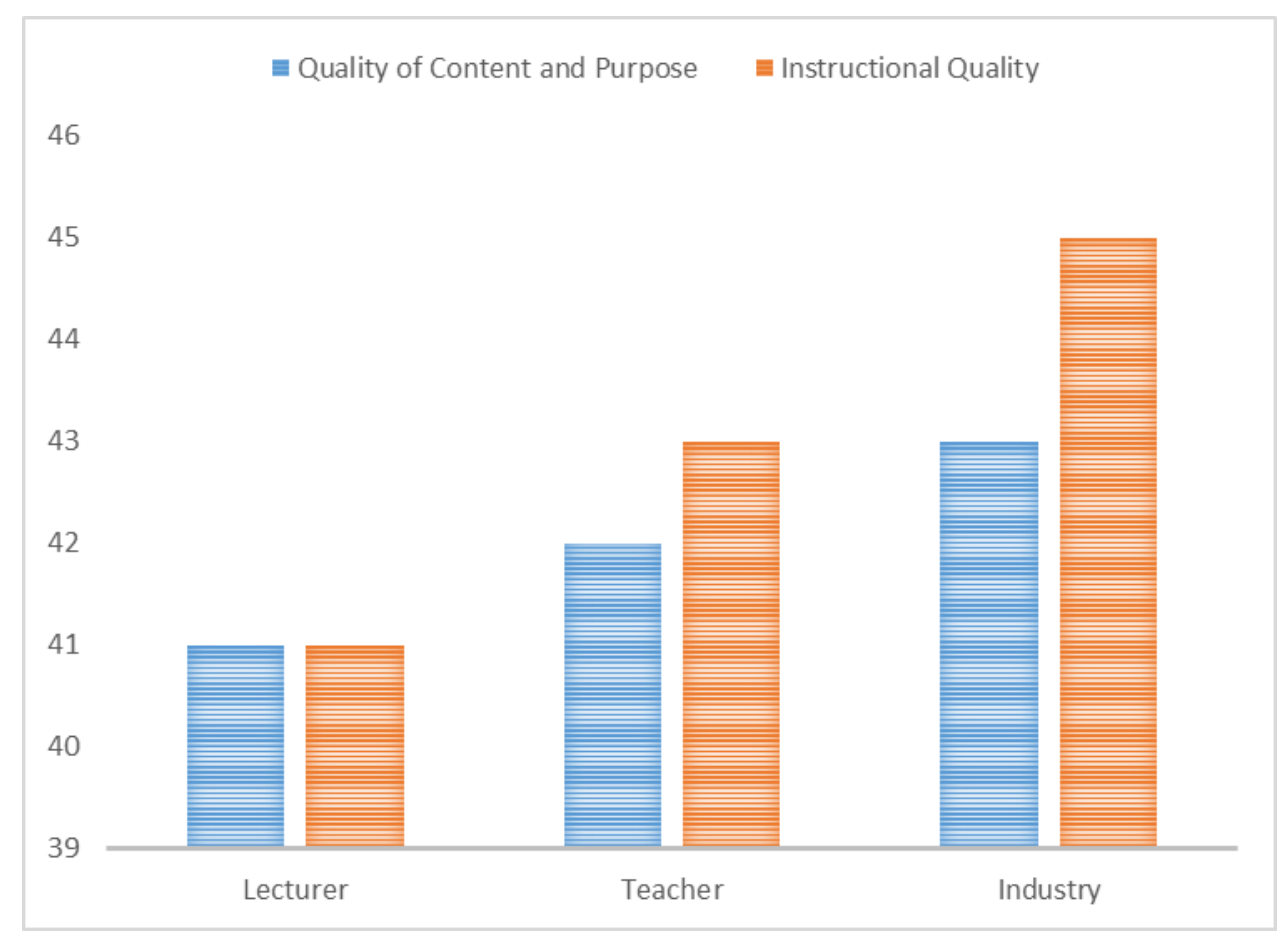

Figure 5. The score of material experts

Thus, the total score obtained with the average score is 85 which states that it is in the $\mathrm{X}$ 85 interval so that the mechatronics trainer job sheet product is categorized as very feasible. In this case, it means that the mechatronics trainer jobsheet in terms of content quality and objectives as well as instructional quality is very good and very suitable to be used as a learning medium. This research is supported by the results of research (John Aldi Prapaskah, et al, 2020), (J. W. Adji, D, 2020), (Hariyanto, D, 2020), (H. Prabowo \& F. Arifin, 2018) regarding the level of eligibility on the jobsheet. It can be concluded, mechatronics trainer josbheet can be used as a learning media in practice for mechatronics trainer learning media.

The results of the mechatronics trainer jobsheet validator show very feasible criteria for aspects of content, language, and material presentation based on quantitative data from validator questionnaire entries and are supported by comments and general suggestions stating that the content of the jobsheet is good and the material covers all learning objectives. The conclusion of the validation results stated that the mechatronics trainer jobsheet as a mechatronic media guide was very feasible to be tested in the field. 


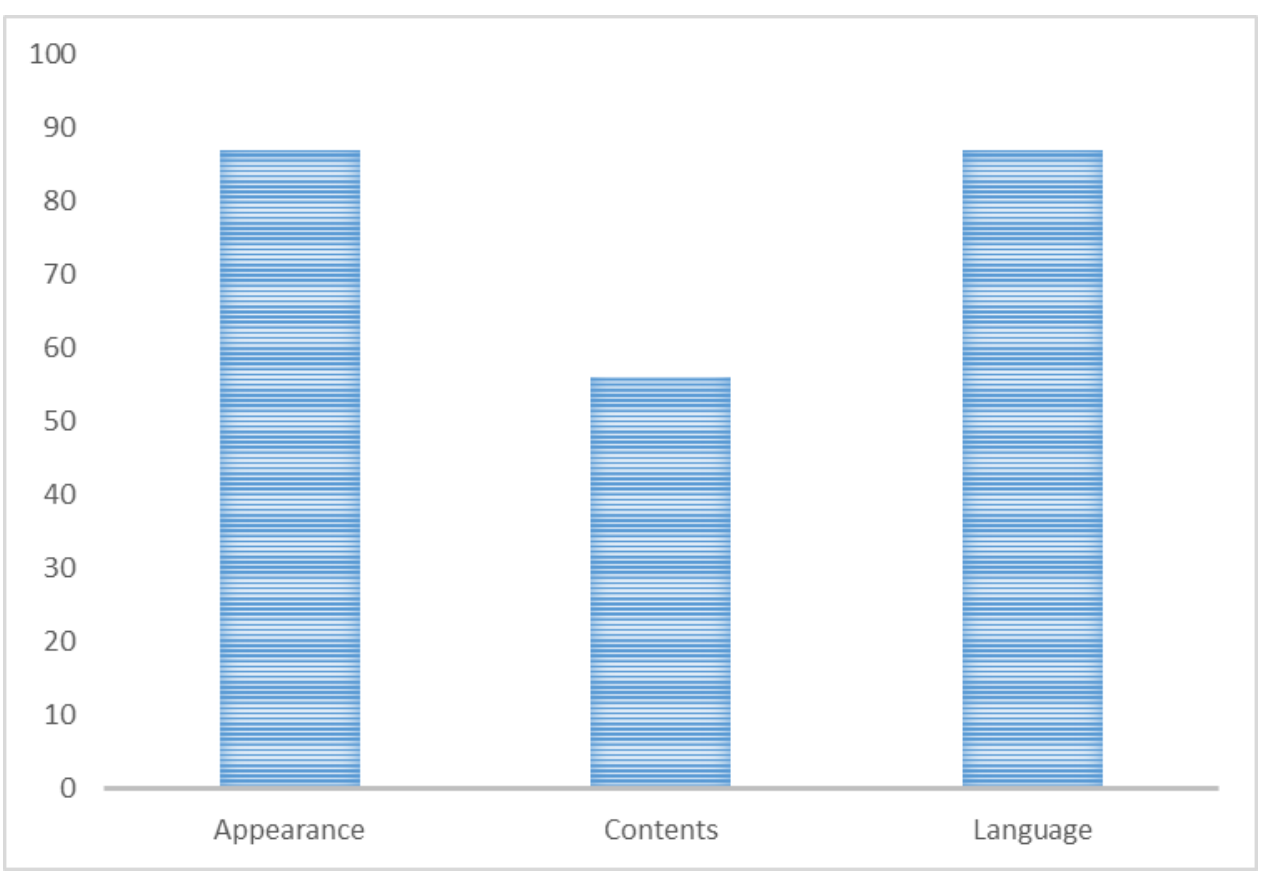

Figure 6. Student response

From the student response test, it can be concluded that the mechatronics trainer media is in the very practical category used in learning mechatronics practice. Thus, with the results that have been obtained, the mechatronics trainer can be used as a practical learning medium for mechatronics courses in the Electrical Engineering Vocational Education study program, Faculty of Teacher Training and Education, Sultan Ageng Tirtayasa University.

The results of testing the effectiveness of the product using the method of giving pretest and posttest to research subjects, the highest score obtained in the pretest was 60 , 3 with an average student score of 40, 2 and in the posttest the highest score was 91, 8 with an average student score is 85,3 . From these data, the N-Gain value can be calculated as follows. From these calculations, the $\mathrm{N}$-gain value is 0.75 or in the high category, so the mechatronics trainer is suitable for use as a practical learning medium.

\section{CONCLUSION}

Based on the results of the research on the development of mechatronic trainer media in the Electrical Engineering Vocational Education study program, Faculty of Teacher Training and Education, Sultan Ageng Tirtayasa University, it can be concluded as follows:

The feasibility level of the mechatronics trainer is based on a feasibility test with three media experts who get a score with a very decent category. The level of feasibility of a mechatronics trainer josbheet with three material experts who got a score with a very decent category. Based on these results, it can be said that mechatronics trainers and josbheet are appropriate to be used as practical learning media in mechatronics courses in the sixth semester, for the Electrical Engineering Vocational Education study program, Faculty of Teacher Training and Education, Sultan Ageng Tirtayasa University. 
The development of the mechatronics trainer media was developed using 4 stages, namely, (1) Defining or analyzing needs, analyzing the needs of the importance of doing development. (2) Design, designing the mechatronics trainer along with its devices related to the mechatronics trainer learning media. (3) Development, ensuring that the products developed are suitable for use or field trials based on expert judgments (4) Dissemination or implementation, implementing products that have been designed and have been appropriate for students to obtain data on the practicality and effectiveness of using media practical learning in mechatronics courses.

\section{REFERENCES}

Anonim, 2002. Curriculum Mechatronics General, part 1, Festo Industry.

Aris, Z. M. 2007. Pengajaran Mekatronika Menggunakan Gambar Animasi Makromedia Flash di Jurusan Teknik Mesin. Seminar Nasional Aplikasi Teknologi Informasi 2007 (SNATI 2007) ISSN: 1907-5022. Yogyakarta, 16 Juni 2007. Hal 9-12.

Benny A. Prasetyo, Dyah Lestari, Siti Sendari. 2017. Pengembangan Bahan Ajar Mekatronika Untuk Program Studi D3 Teknik Elektronika Fakultas Teknik Universitas Negeri Malang. http://journal2.um.ac.id/index.php/tekno | ISSN 1693-8739. TEKNO Vol. 27 Issue 2, pl62-169. Jurnal Teknologi Elektro dan Kejuruan.

Daryanto. 2013. Menyusun Modul Bahan Ajar untuk Persiapan Guru dalam Mengajar. Yogyakarta. Gava Media.

Depdiknas. 2003. Undang-undang RI No. 20 Tahun 2003. Tentang sistem pendidikan nasional.

Djamarah \& Zain. 2006. Strategi belajar mengajar. Jakarta: Rineka Cipta.

H. Prabowo and F. Arifin. 2018. Pengembangan Media Pembelajaran Kendali Fuzzy Logic Berbasis Arduino Nano Pada Mata Kuliah Praktik Sistem Kendali Cerdas. Elinvo (Electronics, Informatics, Vocat. Educ., vol. 3, no. 1, pp. 39-45, 2018.

Hariyanto, D. Aribowo, and M. Fatkhurrokhman. 2020. Pengembangan Media Pembelajaran Trainer Kit Pengendali Motor 3 Phase Pada Mata Pelajaran Instalasi Motor Listrik Di SMKN 4 Kota Serang. JUPITER (Jurnal Pendidik. Teknik. Elektro), vol. 05, pp. 1-7, 2020.

J. W. Adji, D. Aribowo, and M. Fatkhurrohman. 2020. Media Pembelajaran Trainer Kit Elektropneumatik pada Mata Pelajaran Sistem Pengendali Elektronik di SMK Negeri. JUPITER (Jurnal Pendiikan Tek. Elektro), vol. 05, pp. 14-21, 202

Lase, D. 2019. Pendidikan di Era Revolusi Industri 4.0. SUNDERMANN: Jurnal Ilmiah Teologi, Pendidikan, Sains, Humaniora Dan Kebudayaan, 1 (1), 28-43.

Mardapi, D. 2008. Teknik Penyusunan Instrumen Tes dan Nontes. Jogjakarta: Mitra Cendikia

Nur, M. 2005. Pengajaran Langsung. Surabaya: University Press 
Ogata, Katsuhiko. 2002. Modern Control Engineering. New Jersey: Prentice-Hall, Inc.

Prapaskah. Y. A, Permata. E, M. Fatkhurrokhman. 2020. Trainer Kit Pneumatik Sebagai media Pembelajaran pada Mata Kuliah Mekatronika di Program Studi Pendidikan Vokasional Teknik Elektro UNTIRTA. Skripsi Program Studi Pendidikan Vokasional Teknik Elektro FKIP Universitas Sultan Ageng Tirtayasa. Kota Serang-Banten. Tidak Terbitkan.

Rizki, B. C. 2014. Pengembangan Trainer Intalasi penerangan Sebagai Media Pembelajaran Instalasi Listrik Program keterampilan Elektronika di MAN Kendal. http://journal.unnes.ac.id/sju/index.php/eduel. Edu Elektrika Journal. EDUEL 3 (2) (2014). ISSN 2252-7095. Hal. 1-8.

Sadiman, Arif S., Rahardjo, R., Haryono, Anung., Rahardjito. 2011. Pengertian, Pengembangan dan Pemanfaatannya. Jakarta: Raja Grafindo.

Sudira. P, Aini. S. N. 2016. Pengaruh Strategi Pembelajaran, Gaya Belajar, Sarana Praktik, dan Media terhadap hasil Belajar Patiseri SMK se-Gerbang Kertasusila. Jurnal Pendidikan Vokasi. 5 (1). P.88-102.

Sugiyono. 2018. Metode Penelitian Kuantitatif, Kualitatif, dan R\&D. Bandung: Alfabeta.

Tohir, M. 2020. Buku Panduan Merdeka Belajar-Kampus Merdeka. University Press.

Wahyudi, hendra Jaya, Edy Sabara. 2020. Pengembangan Media Trainer Robotika Berbasis Mikrokontroler pada Program Studi Pendidikann Vokasional Mekatronika FT-UNM. Pendidikan Teknologi dan Kejuruan. Pascasarjana Universitas Negeri Makssar. 